\title{
PENGARUH PEMANFAATAAN TEKNOLOGI DAN KOMITMEN ORGANISASI TERHADAP TRANSPARANSI PENGELOLAAN KEUANGAN DAERAH KUALITAS LAPORAN KEUANGAN DAERAH SEBAGAI VARIABEL INTERVENING PADA PROVINSI KEPULAUAN RIAU
}

\author{
Andres Putranta Sitepu \\ Rachmad Chartady \\ STIE Pembangunan Tanjungpinang \\ andresputranta.sitepu231@gmail.com \\ chartady@stie-pembangunan.ac.id
}

\begin{abstract}
Abstrak : Penelitian ini bertujuan untuk mengetahui Pengaruh Pemanfaatan Teknologi dan Komitmen Organisasi Terhadap Transparansi Pengelolaan Keuangan Daerah dengan Kualitas Laporan Keuangan Daerah Sebagai Variabel Intervening pada Pemerintah Provinsi Kepulauan Riau. Jenis penelitian dalah deskriptif kuantitatif, tipe data dan sumber data yang digunakan adalah data primer. Metode pengumpulan data dan pengolahan data dilakukan dengan observasi dan kuesioner di Pemerintah Provinsi Kepulauan Riau dengan Populasi dalam penelitian ini berjumlah 124 karyawan. Dalam penelitian ini penulis mendapatkan sample 103 karyawan yang bekerja di bagian keuangan. Hasil analisis menunjukkan bahwa koefisien efek langsung lebih besar dari pengaruh tidak langsung sebesar 0,385> 0,03, sehingga lebih efektif pengaruh langsung dari pada pengaruh tidak langsungnya.

Maka Pemanfaatan Teknologi Informasi berpengaruh signifikan terhadap Transparansi Pengelolaan Keuangan Daerah tidak melalui Kualitas Laporan Keuangan. Atau dengan kata lain Kualitas Laporan Keuangan bukan variabel intervening antara Pemanfaatan Teknologi Informasi terhadap Transparansi Pengelolaan Keuangan Daerah atau bersifat pengaruh langsung. Sedangkan analisis lebih lanjut menunjukkan koefisien pengaruh tidak langsung lebih besar dari pengaruh langsung sebesar $0.043<0.067$. Komitmen Organisasi berpengaruh signifikan terhadap Transparansi Pengelolaan Keuangan Daerah melalui Kualitas Laporan Keuangan. Atau dengan kata lain Kualitas Laporan Keuangan adalah variabel intervening antara Komitmen Organisasi terhadap Transparansi Pengelolaan Keuangan Daerah atau bersifat pengaruh tidak langsung.
\end{abstract}

Kata Kunci : Transparansi Pengelolaan Keuangan Daerah, Pemanfaatan Teknologi Informasi dan Komitmen Organisasi

Abstract : This study aims to determine the Influence of Technology Utilization and Organizational Commitment to Transparency of Regional Financial Management with Quality of Regional Financial Report as Intervening Variable in The Government of Riau Islands Province. Type of research is quantitative descriptive, data type and data source used is primary data. Methods of data collection and data processing is done by observation and questionnaire in Riau Islands Provincial Government with Population in this research amounted to 124 employees. In this study the authors get a sample of 103 employees working in the financial sector.

The result of analysis shows that the utilization of Information Technology has significant effect to Transparency of Regional Financial Management not through Quality of Financial Report. Or in other words Quality of Financial Statement is not intervening 
variable between Utilization of Information Technology to Transparency of Regional Financial Management or is direct influence. While further analysis shows the Organizational Commitment significantly influence the Transparency of Regional Financial Management through the Quality of Financial Statements. Or in other words the Quality of Financial Statements is an intervening variable between the Organizational Commitment to Transparency of Regional Financial Management or is an indirect influenc.

Keywords: Transparency of Regional Financial Management, Utilization of Information Technology and Organizational Commitment.

\section{PENDAHULUAN}

Dalam rangka meningkatkan transparansi dan akuntabilitas pengelolaan keuangan Negara dimaksud, salah satu upaya yang dilakukan pemerintah adalah menyusun paket undang-undang keuangan negara yaitu: Undang-undang (UU) nomor 17 tahun 2003 tentang Keuangan Negara, UU nomor 01 tahun 2004 tentang Perbendaharaan Negara, dan UU nomor 15 tahun 2004 tentang Pemeriksaan Pengelolaan dan Tanggung Jawab Keuangan Negara. Salah satu upaya konkrit untuk mewujudkan transparansi dan akuntabilitas pengelolaan keuangan negara adalah penyampaian laporan pertanggungjawaban keuangan pemerintah yang memenuhi prinsip-prinsip tepat waktu dan disusun dengan mengikuti standar akuntansi pemerintahan yang telah diterima secara umum. Pada tahun 2005 Pemerintah menetapkan Peraturan Pemerintah (PP) Nomor 24 tahun 2005 tentang Standar Akuntansi Pemerintahan. Dalam perkembangannya, PP Nomor 24 tahun 2005 diperbaharui menjadi PP no 71 tahun 2010 dengan merubah basis kas menuju akrual menjadi penerapan secara total atas basis akrual pada tahun 2015 .
Standar ini dibutuhkan dalam rangka penyusunan laporan pertanggungjawaban pelaksanaan APBN/APBD.

BPKP dalam hal ini Deputi Pengawasan Bidang Penyelenggaraan Keuangan Daerah memberikan respon positif atas terbitnya permendagri ini, dengan menyusun suatu program aplikasi yang dapat digunakan oleh pemda dalam rangka pengelolaan keuangan daerahnya. Program aplikasi dimaksud adalah Program Aplikasi Komputer SIMDA Versi 2.1 yang merupakan pengembangan lebih lanjut dari program aplikasi sebelumnya yaitu SIMDA Versi 2.0. Program aplikasi ini telah diperkenalkan pada tanggal 29 Agustus 2006 pada pelaksanaan kegiatan Forum SAKD di Pusdiklatwas BPK. (situs http://www.bpkp.go.id/sakd/konten/334/Seja rah-SIMDA.bpkp).

Perwujudan dari upaya pemerintah dalam menciptakan pelayanan publik yang transparan adalah dengan diterapkannya egovernment di berbagai instansi ataupun lembaga baik di tingkat pusat maupun daerah. Seperti yang dijelaskan dalam Indrajit (2005:3), Konsep E-Government bukanlah inisiatif yang mudah dan murah. 
Sebelum memutuskan untuk mengalokasikan sejumlah sumber daya yang sangat besar, harus dimengerti terlebih dahulu latar belakang apa yang menyebabkan inisiatif egovernment perlu (atau tidak) untuk diimplementasikan.

Dalam rangka mewujudkan hal tersebut di atas maka diperlukan komitmen organisasi yang kuat. Mengingat perwujudan transparansi tidak terlepas dari kemampuan pemerintah pusat maupun daerah dalam pemanfaatan teknologi informasi sebagai sarana yang menghasilkan informasi yang akurat dan dapat dipercaya serta menghasilkan laporan keuangan yang berkualitas. Untuk itu, keseriusan pemerintah provinsi Kepulauan Riau dalam mewujudkan pemerintahan yang bersih hanya bisa dicapai dengan membangun komitmen organisasi yang berorientasi pada visi dan misi Gubernur Kepulauan Riau, penerapan teknologi informasi yang baik dan berkualitasnya laporan keuangan pemerintah daerah serta informasi mudah diakses oleh publik secara transparan.

Berdasarkan uraian latar belakang penelitian diatas, maka dapat dirumuskan beberapa permasalahan yang akan diteliti diantaranya :

$\begin{array}{llr}\text { 1. Apakah Pemanfaatan } & \text { Teknologi } \\ \text { Informasi } & \text { Informasi } & \text { berpengaruh } \\ \text { langsung } & \text { terhadap } & \text { Transparansi } \\ \text { Pengelolaan Keuangan Daerah? } \\ \text { 2. Apakah Komitmen } & \text { Organisasi } \\ & \text { berpengaruh langsung terhadap }\end{array}$

Transparansi Pengelolaan Keuangan Daerah?

3. Apakah Kualitas Laporan Keuangan berpengaruh langsung terhadap Transparansi Pengelolaan Keuangan Daerah?

4. Apakah Pemanfaatan Teknologi Informasi berpengaruh langsung terhadap Kualitas Laporan Keuangan?

5. Apakah Komitmen Organisasi berpengaruh langsung terhadap Kualitas Laporan Keuangan?

\section{METODOLOGI PENELITIAN}

Penelitian ini menggunakan pendekatan penelitian kuantitatif yang memfokuskan pada pengujian hipotesis untuk menemukan kebenaran dari hipotesis yang selanjutnya dilakukan uji statistik untuk memberikan informasi dan penjelasan berupa data-data yang akurat agar dapat dianalisis lebih lanjut (Sugiyono 2011:11).

Berdasarkan tujuan penelitian, yaitu ingin menguji menguji pengaruh Pemanfaatan Teknologi Informasi dan Komitmen Organisasi terhadap Transparansi, dengan Kualitas Laporan Keuangan Daerah sebagai variabel intervening di Pemerintah Provinsi Kepulauan Riau. Sifat dari penelitian ini dikategorikan penelitian penjelasan atau eksplanatory research, dimana menjelaskan hubungan dan pengaruh melalui pengujian hipotesis.

Populasi target pada penelitian ini adalah seluruh Pegawai Penyusun Laporan Keuangan Di Pemerintah Daerah Provinsi Kepulauan Riau yaitu Pejabat Penata 
Usahaan Keuangan OPD, Bendahara Pengeluaran OPD, Kepala Sub Bagian Keuangan dan Kepala Sub Bagian Perencanaan pada 39 (tiga puluh sembilan) Organisasi Perangkat Daerah Pemerintah Provinsi Kepulauan Riau berjumlah 124 pegawai. Adapun populasi yang akan diteliti ini akan diberikan kriteria yang sesuai dengan standar pengambilan data yang akan dijadikan sampel penelitian.

Penelitian ini di sesuaikan menjadi sebanyak 103 atau sebesar 83,06\% dari 39 OPD, hal ini dilakukan untuk mempermudah dalam pengolahan data dan untuk hasil pengujian yang lebih baik. Sampel yang diambil berdasarkan teknik probability sampilng; simple random sampling, dimana peneliti memberikan peluang yang sama bagi setiap anggota populasi untuk dipilih menjadi sampel yang dilakukan secara acak tanpa memperhatikan strata yang ada dalam populasi itu sendiri (Sugiyono 2011 : 63).

Pengambilan dan pengumpulan data dalam penelitian ini dilakukan dengan cara menyebarkan kuisioner kepada responden penelitian. Kuesioner adalah suatu sarana berupa daftar isian yang berisi beberapa pertanyaan yang berkaitan dengan variabel dalam penelitian ini. Kuisioner tersebut disebarkan kepada responden.

Pengukuran data yang dilakukan dalam penelitian ini adalah Skala interval. Skala pengukuran merupakan kesepakatan yang digunakan sebagai acuan untuk menentukan panjang pendeknya interval yang ada dalam alat ukur, sehingga alat ukur tersebut bila digunakan dalam pengukuran akan menghasilkan data kuantitatif. Skala interval biasa dipakai oleh para ahli sosial untuk mengukur fenomena atau gejala sosial. (Sugiyono, 2010).

Skala atau tingkat pengukuran adalah abstrak tetapi penting dan secara luas digunakan dalam penelitian kuantitatif. Skala ukuran dalam penelitian kuantitatif penting karena : 1) Tanpa skala, tidak mungkin dilakukan pengukuran atau tidak mungkin ditentukan nilai atau skor kesatuan pada variabel; 2) Tanpa skala, pemilihan metode atau teknik pengumpulan data tidak dapat ditentukan berdasarkan alasan-alasan rasional (rational principle); 3) Skala untuk variabel perlu ditentukan oleh karena ukuran-ukuran dan pengujian statistik; 4) Tiap skala tersebut menyebabkan penggunaan uji statistik yang berlainan. (Silalahi, 2009).

Dengan demikian terdapat beberapa teknik penskalaan atau pengkonstruksian skala yang secara umum digunakan dalam penelitian sosial antara lain; skala Likert (Likert scale), skala perbedaan semantik (semantic diffrential scale), skala Guttman (Guttman scale) atau skalo gram, skala Thurstone (Thurstone scale), dan skala Bogardus.

Berdasarkan uraian diatas maka penulis menggunakan skala Likert dengan ukuran sebagai berikut: Sangat Setuju = diberi skor 5; Setuju = diberi skor 4; Ragu- 
ragu/Tidak Pasti $=$ diberi skor 3 ; Tidak Setuju $=$ diberi skor 2; Sangat Tidak Setuju $=$ diberi skor 1 .

Dalam penelitian ini Variabel bebas adalah Pemanfaatan Teknologi Informasi $\left(\mathrm{X}_{1}\right)$ dan Komitmen Organisasi $\left(\mathrm{X}_{2}\right)$ sementara variabel terikatnya adalah Transparansi Pengelolaan Keuangan Daerah yang selanjutnya disimbolkan dengan (Y), kemudian Variabel Intervening dalam penelitian ini adalah Kualitas Laporan Keuangan Daerah (Z). Kesemua variabel ini berupa kuisioner yang disebarkan dengan scoring model skala Likert yang diisi oleh responden.

\section{HASIL DAN PEMBAHASAN}

Berdasarkan uji hipotesis yang telah dilakukan, maka dapat ditafsirkan hasil penelitian sebagai berikut.

1. Pengaruh Pemanfaatan Teknologi Informasi terhadap Transparansi Pengelolaan Keuangan Daerah

Pengujian terhadap hipotesis 1 menyatakan bahwa Pemanfaatan Teknologi Informasi berpengaruh langsung secara positif terhadap Transparansi Pengelolaan Keuangan Daerah, hal ini dapat kita lihat dari hasil pengolahan SPSS dengan Kriteria Pengujian Hipotesis sebesar $0.000<0.05$ dan $\mathrm{t}$ hitung $4.027>\mathrm{t}$ tabel 1.937 , hal ini menunjukan bahwa variabel eksogen penerapan Pemanfaatan Teknologi Informasi berpengaruh secara signifikan terhadap variabel endogen Transaparansi Pengelolaan Keuangan Daerah.

Pengaruh tersebut yang dapat dilihat pada analisis jalur di atas pengaruh langsung dari hipotesis ini yang ditunjukan oleh koefisien jalur sebesar 0.40 lebih besar dari koefisien jalur tidak langsungnya sebesar 0.003. Hal ini mempunyai makna bahwa pengaruh yang sebenarnya dari Pemanfaatan Teknologi Informasi berpengaruh langsung secara positif terhadap Transpansi Pengelolaan Keuangan Daerah adalah pengaruh langsung. Koefisien jalur sebesar 0.40 dapat di artikan bahwa Pemanfaatan Teknologi Informasi berkontribusi $40 \%$ dalam mempengaruhi Transpansi Pengelolaan Keuangan Daerah.

\section{Pengaruh Komitmen Organisasi terhadap Transparansi Pengelolaan Keuangan Daerah}

Pengujian terhadap hipotesis 2 menyatakan bahwa Pengaruh Komitmen Organisasi terhadap Transparansi Pengelolaan Keuangan Daerah, hal ini dapat kita lihat dari hasil pengolahan SPSS dengan sig a sebesar $0.663>0.05$ dan $\mathrm{t}$ hitung 0.438 $<\mathrm{t}$ tabel 1.937, hal ini menunjukan bahwa Komitmen Organisasi tidak berpengeruh langsung secara positif terhadap Transparansi Pengelolaan Keuangan Daerah. Hal ini memperhatikan analisis jalur diatas pengaruh langsung dari hipotesis ini yang ditunjukan oleh koefisien jalur sebesar 0.043 lebih kecil dari koefisien jalur tidak langsungnya sebesar 0.06. Hal ini 
mempunyai makna bahwa Komitmen Organisasi berpengaruh langsung secara positif terhadap Transparansi Pengelolaan Keuangan Daerah adalah pengaruh tidak langsung. Koefisien jalur sebesar 0.043 dapat di artikan bahwa Komitmen Organisasi berkontribusi $4,3 \%$ dalam mempengaruhi Transparansi Pengelolaan Keuangan Daerah.

\section{Pengaruh Kualitas Laporan Keuangan terhadap Transparansi}

Pengujian terhadap hipotesis 3 menyatakan bahwa pengaruh Kualitas Laporan Keuangan Daerah terhadap Transparansi Pengelolaan Keuangan Daerah dapat kita lihat dari hasil pengolahan data dari SPSS dengan sig a sebesar sebesar $0.796>0.05$ dan $t$ hitung $2.092>\mathrm{t}$ tabel 1.937, Hasil ini memberi kesimpulan bahwa Kualitas Laporan Keuangan berpengaruh tidak langsung secara positif terhadap Transparansi Pengelolaan Keuangan Daerah di Pemerintah Provinsi Kepulauan Riau.

Dengan memperhatikan analisis jalur di atas pengaruh tidak langsung dari hipotesis ini yang ditunjukan oleh koefisien jalur sebesar 0.025 kecil dari koefisien jalur tidak langsungnya sebesar 0.049 hal ini mempunyai makna bahwa Kualitas Laporan Kuangan berpengaruh langsung secara positif terhadap Transparansi Pengelolaan Keuangan Daerah di Pemerintah Provinsi Kepulauan Riau. Koefisien jalur sebesar 0.025 dapat di artikan bahwa Kualitas Laporan Keuangan Daerah berkontribusi
2,5\% dalam mempengaruhi Transparansi Pengelolaan Keuangan Daerah.

\section{Pengaruh Penerapan Pemanfaatan Teknologi Informasi terhadap Kualitas Laporan Keuangan}

Pengujian terhadap hipotesis 4 menyatakan bahwa penerapan Pemanfaatan Teknologi Informasi berpengaruh langsung secara positif terhadap Kualitas Laporan Keuangan, hal ini dapat kita lihat dari hasil pengolahan SPSS pada tabel dengan sig $a$ sebesar $0.255>0.05$ dan $\mathrm{t}$ hitung $1.145<\mathrm{t}$ tabel 1.937, hal ini menunjukan bahwa penerapan Pemanfaatan Teknologi Informasi berpengaruh langsung secara positif terhadap Kualitas Laporan Keuangan . analisis jalur diatas pengaruh langsung dari hipotesis ini yang ditunjukan oleh koefisien jalur sebesar 0.187. Hasil ini memberi kesimpulan bahwa Pemanfataan Teknologi Informasi tidak berpengaruh langsung secara positif terhadap Kualitas Laporan Keuangan Daerah, hal ini mempunyai makna bahwa Pemanfaatan Teknologi Informasi berkontribusi 25,5\% dalam mempengaruhi Kualitas Laporan Keuangan Daerah.

\section{Pengaruh Komitmen Organisasi terhadap Kualitas Laporan Keuangan}

Pengujian terhadap hipotesis 5 menyatakan bahwa Pengaruh Komitmen Organisasi terhadap Kualitas Laporan Keuangan Daerah hal ini dapat kita lihat dari hasil pengolahan SPSS dengan sig a sebesar 0.038 atau $<0.05$ dan t hitung $2.101>\mathrm{t}$ tabel 
1.97, hal ini menunjukan bahwa Komitmen Organisasi berpengaruh langsung secara positif terhadap Kualitas Laporan Keuangan dengan memperhatikan analisis jalur diatas pengaruh langsung dari hipotesis ini yang ditunjukan oleh koefisien jalur sebesar 0.182 dapat di artikan bahwa Komitmen Organisasi mempunyai berkontribusi $18.2 \%$ dalam mempengaruhi Kualitas Laporan Keuangan di Provinsi Kepulauan Riau.

\section{PENUTUP}

\section{Simpulan}

Berdasarkan hasil penelitian yang telah dilakukan, maka dapat disimpulkan beberapa hal sebagai berikut :

Berdasarkan penelitian diatas dapat di simpulkan pengaruh pengaruh Pemanfaatan teknologi informasi dan komitmen organisasi terhadap transparansi pengelolaan keuangan daerah dengan kualitas laporan keuangan daerah sebagai variable intervening di Pemerintah Provinsi Kepulauan Riau sebagai berikut :

1. Pemanfaatan Teknologi Informasi berpengaruh langsung secara positif dan signifikan terhadap Transparansi.

2. Komitmen Organisasi berpengaruh tidak langsung secara positif dan signifikan terhadap.

3. Kualitas Laporan Keuangan Daerah berpengaruh tidak langsung secara positif dan signifikan terhadap Transparansi.

4. Pemanfaatan Teknologi Informasi berpengaruh tidak langsung secara positif dan signifikan terhadap Kualitas Laporan Keuangan Daerah.

5. Komitmen Organisasi berpengaruh langsung secara positif dan signifikan terhadap Kualitas Laporan Keuangan Daerah.

6. Pemanfaatan Teknologi Informasi berpengaruh signifikan terhadap Transparansi Pengelolaan Keuangan Daerah tidak melalui Kualitas Laporan Keuangan Daerah. Atau dengan kata lain Kualitas Laporan Keuangan Daerah bukan variabel intervening antara Pemanfaatan Teknologi Informasi dengan Transparansi Pengelolaan Keuangan Daerah. Hal ini menunjukan bahwa pengaruh yang sebenarnya antara Pemanfaatan Teknologi Informasi berpengaruh signifikan terhadap Transparansi adalah pengaruh langsung.

7. Komitmen Organisasi berpengaruh signifikan terhadap Transparansi Pengelolaan Keuangan Daerah melalui Kualitas Laporan Keuangan Daerah. Atau dengan kata lain Kualitas Laporan Keuangan Daerah merupakan variabel intervening antara Komitmen Organisasi dengan Transparansi Pengelolaan Keuangan Daerah. Hal ini menunjukan bahwa pengaruh yang sebenarnya antara Komitmen Organisasi berpengaruh signifikan terhadap Transparansi Pengelolaan Keuangan Daerah adalah pengaruh tidak langsung. 


\section{Saran}

Berdasarkan kesimpulan diatas, dapat disampaikan saran-saran sebagai berikut :

1. Disarankan kepada Pemerintah Provinsi Kepulauan Riau untuk dapat lebih maksimal dalam pemanfaatan teknologi informasi dalam pengelolaan keuangan daerah, khususnya penguatan sarana dan prasarana Teknologi Informasi.

2. Pemerintah Provinsi Kepulauan Riau lebih berkomitmen melaksanakan azaz Transparan dalam pengelolaan keuangan daerah guna terwujudnya pemerintahan yang baik dan bersih.

3. Pemerintah Provinsi Kepulauan Riau untuk dapat segera menerapkan $e$ government dalam pengelolaan roda pemerintahan khusunya terkait pengelolaan keuangan daerah.

4. Pemerintah Provinsi Kepulauan Riau dapat lebih meningkatkan kualitas laporan keuangan daerah, sehingga kedepannya Penyampaian dan Publikasi Laporan Keuangan Daerah dapat dilaksanakan dan meminimalisir terjadinya temuan - temuan dalam pengungkapan Laporan Keuangan oleh BPK.

5. Saran yang dapat penyusun sampaikan sehubungan dengan hasil penelitian untuk perbaikan, penelitian selanjutnya diharapkan peneliti dapat melakukan penyelidikan yang serupa dengan menggunakan variabel-variabel lain yang berpengaruh terhadap Transparansi dengan memperbaiki kelemahan dari penelitian sebelumnya serta memperbanyak jumlah populasi yang ada guna memenuhi kebutuhan sample penelitian.

\section{DAFTAR PUSTAKA}

Aliyah, Siti, ed. 2012. Pengaruh Penyajian Laporan Keuangan Daerah Dan Aksesibilitas Laporan Keuangan Daerah Terhadap Transparansi Dan Akuntabilitas Pengelolaan Keuangan Daerah Kabupaten Jepara. Jurnal Akuntansi \& Auditing Volume 8/No. 2/Mei 2012: 97-189

Ashworth, R., G. Boyne., dan R. Delbridge. 2009. Escape from the Iron Cage? Organizational Change and Isomorphic Pressures in the Public Sector. Journal of Public Administration Research and Theory.

Bandary, Himmah. 2011. "Pengaruh Penyajian Laporan Keuangan Daerah Dan Aksesibilitas Laporan Keuangan Terhadap Penggunaan Informasi Keuangan Daerah (Studi Pada Kabupaten Eks Karesidenan Banyumas)". Skripsi. Semarang: fakultas Ekonomi, Universitas Diponegoro.

Diamond, Jack, 2002, "Performance Budgeting Is Accrual Accounting Required?".

IMFWorking Paper. Fiscal Affairs Department.

Diana, Sari. 2012. Pengaruh Pengendalian Internal Terhadap Transparansi Laporan Keuangan Pemerintah Daerah. Bandung: SNAB Perkembangan Peran Akuntansi Dalam Bisnis Yang Profesional 
DiMaggio, P. J. dan W. W. Powell. 1983. The Iron Cage Revisited: Institutional Isomorphism and Collective Rationality in Organizational Fields. American Sociological Review.

Frumkin, P. dan J. Galaskiewicz. 2004. Institutional Isomorphism and Public Sector Organizations. Journal of Public Administration Research and Theory.

Ghozali, Imam. 2005. "Teori, Konsep, Aplikasi Dengan Program Lisrel”. Semarang: Badan Penerbit Universitas Diponegoro.

Ghozali, Imam. 2011. "Aplikasi Analisis Multivariate dengan Program SPSS Alfabeta Semarang: Badan Penerbit Universitas Diponegoro

Mardiasmo. 2006. Perwujudan Transparansi dan Akuntabilitas Publik Melalui Akuntansi Sektor Publik: Suatu Sarana Good Governace. Jurnal Pemerintah, Vol 2, No.1, Hal 1-17

Mizruchi, M. S. dan L. C. Fein. 1999. The Social Construction of Organizational Knowledge A Study of the Uses of Coercive, Mimetic, and Normative Isomorphism. Administrative Science Quarterly.

Mulyana, Budi. 2006. "Pengaruh Penyajian Neraca Daerah dan Aksesibilitas Laporan Keuangan Terhadap Transparasi dan Akuntabilitas Pengelolaan Keuangan Daerah".Jurnal Akuntansi Pemerintahan.

Mursyidi. 2009. Akuntansi Pemerintahan di Indonesia. Bandung : Penerbit PT. Refika Aditama.

Nasution, Saufi Iqbal (2009). Pengaruh Penyajian Neraca SKPD Dan Aksesibilitas Laporan Keuangan SKPD terhadap Transparansi dan Akuntabilitas Pengelolaan
Keuangan SKPD Di Pemerintah Provinsi Sumatera Utara. Skripsi. Universitas Sumatera Utara Fakultas Ekonomi Medan (tidak dipublikasikan).

Noor, Juliansyah. 2014. Analisis Data Penelitian Ekonomi dan Manajemen. Jakarta: Grasindo.

Ridha. Basuki. 2012. Pengaruh Tekanan Eksternal, Ketidakpastian Lingkungan, dan Komitmen Organisasi Terhadap Penerapan Transparansi Pelaporan Keuangan. SNA BANJARMASIN.

Rumengan, Jemmy. 2010. Metodologi Penelitian Dengan SPSS. UNIBA Press. Batam

Satyaningsih, et, el. 2014. Pelaksanaan Anggaran Berbasis Kinerja Terhadap Penerapan Transparansi Pelaporan Keuangan Daerah (Studi Pada SKPD Kabupaten Klungkung). Vol 2 No.1 tahun 2014. Jurnal Akuntansi Program S1: Universitas Pendidikan Ganesha.

Sihaloho, Johannes. 2013. Pengaruh Tekanan Eksternal, Ketidakpastian Lingkungan Dan Komitmen Manajemen Terhadap Penerapan Transparansi Pelaporan Keuangan (Studi Pada Satuan Kerja Perangkat Daerah Pemerintah Kabupaten Rokan Hilir. Fakultas Ekonomi Akuntansi: Universitas Riau.

Shende, Suresh dan Tony Bennet. 2004. Concept Paper 2: "Transparency and Accountability in Public Financial Administration. UN DESA.

Tuttle, B. dan J. Dillard. 2007. Beyond Competition: Institutional Isomorphism in U.S. Accounting Research. Accounting Horizons. 
Sabar, Rutoto. 2007. Pengantar Metedologi Penelitian. FKIP: Universitas Muria Kudus

Sariningtya, Eka. 2016. Analisis karakteristik individu dan motivasi Intrinsik terhadap komitmen organisasi dengan Kepuasan kerja sebagai variabel intervening (Studi pada PDAM Tirta Mulia Kabupaten Pemalang). Jurnal. Semarang

Sekaran, Uma dan Bougie, Roger. 2013. Research Methods for Business. United Kingdom: Jhon Wiley \& Sons Ltd.

Silalahi, Ulber. 2009. Metode Penelitian Sosial. Bandung; PT. Refika Aditama
Siregar. 2013. Statistika Deskriptif untuk Penelitian. Penerbit PT Raja Grafindo Persada, Jakarta

Sofyandi dan Garniwa. 2007. Perilaku Organisasional. Edisi Pertama. Graha Ilmu, Yogyakarta.

Sugiyono, (2011). Metode Penelitian Pendidikan ( Pendekatan. Kuantitatif, Kualitatif, dan R\&D); Alfabeta. Bandung.

Sumadi, Suryabrata. 2011. Metodologi Penelitian. Jakarta: Raja Grafindo Persada 